LACKOVÁ, M.: Interlingválne homonymá v súčasných slovanských jazykoch. Žilina: EDIS - vydavatel'ské centrum Žilinskej univerzity, 2015. 113 s. ISBN 978-80-554$-1041-8$.

LOTKO, E.: Zrádná slova v polštině a češtině. Olomouc: Filozofická fakulta Univerzity Palackého, 1987. $53 \mathrm{~s}$.

ORGOŇOVÁ, O.: Falošní priatelia (faux-amis) v jazykových kontaktoch slovenčiny $s$ francúzštinou. In: MISTRÍK, J. (red.): Studia Academica Slovaca 2o. Prednášky XXVII. letného seminára slovenského jazyka a kultúry. Bratislava: Alfa, 1991, s. 193-212.

PANČÍKOVÁ, M.: Niekolko príkladov medzijazykovej homonymie - slovinčina, slovenčina. In: Mednarodni simpozij Obdobja. Ljubljana: Center za slovenščino kot drugi/tuji jezik pri oddelku za slovenistiko Filozofske fakultete, 2003, s. 495-500.

PANČÍKOVÁ, M.: Zradné slová v blízkych jazykoch. In: České, polské a slovenské jazykové a literární souvislosti. Sborník z mezinárodní konference uspořádané u př́ležitosti jubilea prof. Edvarda Lotka 20. února 2002. AUPO, Facultas Philologica. Philologica 78. Olomouc: Univerzita Palackého, 2003, s. 27-31. ISBN 80-244-0628-4. TRUP, L.: Problematika „zradných slov" $v$ slovenčine a španielčine. Slovenská reč, roč. 46 , 1981, č. 4, s. 212-221. Bez ISSN.

VAŇKO, J.: Slovinsko-slovenská interlingválna homonymia. Slavia, roč. 73, 2004, sešit 1, s. 59-70. ISSN 0037-6736.

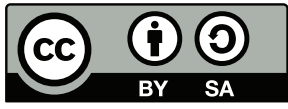

This work can be used in accordance with the Creative Commons BY-SA 4.0 International license terms and conditions (<https://creativecommons.org/licenses/by-sa/4.0/legalcode>). This does not apply to works or elements (such as images or photographs) that are used in the work under a contractual license or exception or limitation to relevant rights.

\title{
https://doi.org/10.5817/OS2020-2-8
}

\section{Stránky z bulharské literatury}

ПАЦЕВА, М., РУНЕВСКА, Е., ПАНОВА, Ст. (съст.) Страници от българската литература. Кратка учебна антология. София: Софийски университет „Св. Климент Охридски“, 2019, 235 с., ISBN 978-619-7433-21-о.

Stránky z bulharské literatury představuje antologii vybraných děl bulharské literatury určenou studijním účelům. Posloužit by měla především bulharským a zahraničním studentům bulharistiky, jistě ji ale přivítá každý, kdo projevuje zájem o bulharskou literaturu. Antologii sestavily odbornice ze Sofijské univerzity sv. 
Klimenta Ochridského Mirena Pacevová, Elena Runevská a Stanka Panovová. Tato pomůcka byla vytvořena v souladu s nejnovějším doporučením doplňujícím Společný evropský referenční rámec pro jazyky, který poskytuje všeobecný základ pro vytváření jazykových sylabů, kde je také zahrnuta četba literárních textů ve volném čase studentů jako součást jejich samostatné př́pravy, jakož i rozvíjení dovedností formování a vyjadřování vlastního názoru inspirovaného literárním textem. Tato antologie vychází též vstříc potřebě sestavit a používat ve výuce digitální studijní materiály, které obecně rychle zprostředkovávají přístup $\mathrm{k}$ informacím a zároveň usnadňují práci během seminářů a hodin praktického bulharského jazyka pro cizince (poslech, čtení, diskuse, aktivity ve skupinách, vytváření různých typů textů). Zároveň slouží i samostatné četbě při domácí př́ípravě.

Texty v antologii bulharské literatury, kterých je více než 70 (od více než 4 o klasických i současných bulharských autorů), reprezentují období od národního obrození až po současnost. Uvedené texty jsou autentické a byly vybrány tak, aby s nimi studenti byli schopni pracovat především samostatně. $V$ antologii jsou zastoupena díla nebo úryvky z děl mnoha žánrů, a to jak z poezie, tak i z prózy a dramatu. Každý umělecký text je opatřen stručným medailonem jeho autora, poznámkami o základních tématech a myšlenkách jeho tvorby a rovněž informacemi o díle, které je $\mathrm{v}$ antologii zařazeno. Př́ručka disponuje rovněž bohatým doplňujícím materiálem fotografiemi a odkazy na různorodé online zdroje (audiozáznamy bulharských herců, kteří čtou úryvky z prezentovaných děl; stránky, které obsahují stručný obsah celého díla; písně inspirované bulharskou literaturou; různojazyčné překlady těchto textů, jež jsou dostupné online apod.).

Velmi př́nosná a pro zahraniční bulharisty zvlášt cenná jsou vysvětlení zastaralých nebo nářečních slov, církevněslovanských výrazů, konkrétních a abstraktních slov, termínů, ustálených slovních spojení, neologismů, nespisovných a slangových obratů, některých cizích slov, jakož i reálií a některých procesů, jejichž nepochopení by mohlo bránit celkovému porozumění textu. U víceznačných slov je uveden jen ten význam, se kterým se slovo vyskytuje v představeném textu. Vysvětlení významu slov vychází ze Slovníku bulharského jazyka Bulharské akademie věd (Речник на българския език на БАН) dostupného online, autorky antologie se snažily maximálně zjednodušit a zpř́stupnit zahraničním studentům pochopení těchto problematických míst. Slova a objasnění jejich významů jsou uvedená $v$ tom pořadí, $v$ jakém na ně čtenář narazí $\mathrm{v}$ textu. Pokud to bylo žádoucí, autorky $\mathrm{k}$ textu připojily i stylistické poznámky, které upřesňují kontext použití toho kterého slova.

Na konci antologie jsou témata a otázky $\mathrm{k}$ diskusi a esejům, seznam zkratek a samozřejmě bibliografie. Př́stup $\mathrm{k}$ antologii je volný a je maximálně usnadněn, protože její lokalizace je na stránkách Fakulty slovanských filologií Sofijské univerzity sv. Klimenta Ochridského: https://www.slav.uni-sofia.bg/images/stories/documents/ 
2019-Antologia.pdf. Texty zahrnuté do této př́ručky představují pro zahraniční studenty dobrou př́ležitost k tomu, aby se hlouběji seznámili s takovou kulturou, zvyky a vnímáním světa, jaké jsou charakteristické pro bulharskou literaturu posledních přibližně 150 let.

Elena Krejčová

\section{Literatura:}

PACEVA, M., RUNEVSKA, E., PANOVA, St. (săst.) Stranici ot bălgarskata literatura. Kratka učebna antologija. Sofija: Sofijski universitet „Sv. Kliment Ochridski“, 2019, 235 s., ISBN 978-619-7433-21-o.

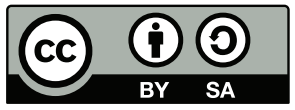

Toto dílo Ize užít v souladu s licenčními podmínkami Creative Commons BY-SA 4.0 International (<https:// creativecommons.org/licenses/by-sa/4.0/legalcode>). Uvedené se nevztahuje na díla či prvky (např. obrazovou či fotografickou dokumentaci), které jsou v díle užity na základě smluvní licence nebo výjimky či omezení př́slušných práv.

\section{K fungování analytických adjektiv v ruštině, češtině a polštinĕ}

PLESNIKK, L.: Typologická charakteristika tzv. analytických adjektiv (na př́kladovém materiálu ruštiny, češtiny a polštiny). Ostrava: Ostravská univerzita, 2019, 218 s. ISBN 978-80-7599-095-2.

Autorem posuzované monografie je ostravský slavista Mgr. Lukáš Plesník, Ph.D. Jak vyplývá z názvu, rozebírá v ní z komparativního hlediska fungování tzv. analytických adjektiv $\mathrm{v}$ ruštině, češtině a polštině, a to na základě shromážděného reprezentativního dokladového materiálu a následně provedené jeho sémantické, strukturní a etymologické analýzy. Publikace vychází z úspěšně obhájené disertační práce autora. Při př́ípravě vydání monografie byly některé původní pasáže revidovány, opatřeny novým strukturním uspořádáním a také doplněny dalšími novými poznatky ze zkoumané problematiky.

V úvodu práce (s. 8-12) věnuje autor pozornost problému nevyhraněnosti terminologického pojmosloví užívaného při zkoumání tzv. analytických adjektiv. Koncepčně vychází z prvotních teorií ruských jazykovědců A. A. Reformatského a M. V. Popova. 